\title{
Effects of alternate-day prednisone therapy on respiratory function in myasthenia gravis ${ }^{1}$
}

\author{
HAROLD H. NEWBALL ${ }^{1}$ and SAMIA. BRAHIM \\ Department of Medicine, The Johns Hopkins University School of Medicine, \\ Baltimore, Maryland, USA
}

\begin{abstract}
Newball, H. H. and Brahim, S. A. (1976). Thorax, 31, 410-413. Effects of alternate-day prednisone therapy on respiratory function in myasthenia gravis. To determine the effects of alternate-day prednisone therapy on respiratory function in myasthenia gravis, eight patients were evaluated during 'days on' and 'days off' prednisone. The patients were treated with long-term (up to three years), high-single-dose, alternate-day oral prednisone. After patients had been controlled with alternate-day prednisone they had no episodes of acute respiratory insufficiency or myasthenic crises. Although a small reduction in respiratory function during the day off prednisone was seen in some patients, the change was not statistically significant for the group and was probably physiologically unimportant in most patients. The data indicate that in myasthenic patients who have no underlying lung disease respiratory function is not significantly compromised by administering the prednisone on alternate days.
\end{abstract}

The most feared complication of myasthenia gravis is the development of a 'crisis'. This term is applied to a myasthenic patient whenever respiratory distress and ventilatory inadequacy occur. One problem of therapy is that the disease affects different muscles to different degrees. The dose of anticholinesterase which relieves ophthalmoplegia, for example, may paralyse the respiratory muscles. When this is seen, the most important endpoint, namely respiratory function, should be used to determine the optimum dosage of therapy.

Recently a new mode of therapy was introduced for patients with myasthenia gravis. It consisted of long-term, high-single-dosage $(100 \mathrm{mg})$, alternateday oral prednisone (Warmolts and Engel, 1972). Because there are significantly fewer side effects of alternate-day versus daily prednisone therapy (Harter, Reddy, and Thorn, 1963), the former is preferable.

The object of the present study is to determine whether alternate-day prednisone therapy is associated with significant fluctuations of respiratory function in myasthenic patients.

\section{MATERIAL AND METHODS}

PATIENTS Eight patients being followed regularly by the Medical Neurology Service (Table I) were

'Supported in part by a SCOR grant (HL-14153) from the NHLI admitted to the pulmonary ward for these studies. The diagnosis of myasthenia gravis was established $\varrho^{\circ}$ by a characteristic medical history and electromyogram and a positive Tensilon test. The patients were started on at least $100 \mathrm{mg}$ of orat prednisone on alternate days, and the dose was. slowly tapered as the disease was controlled (Warmolts et al., 1972). All anticholinergic drugs werę withdrawn. At the time of respiratory function evaluation the disease was considered well con-3 trolled in all subjects. Seven had no history of pulmonary disease except for previous episodes of acute respiratory insufficiency associated with myasthenic crises. Patient 8 was unaware of his obstructive lung disease until the onset of myasthenia gravis.

METHODS Respiratory function was determined at least four times during the day. These times were usually at $8.00 \mathrm{am}, 11.00 \mathrm{am}, 2.00 \mathrm{pm}$, and $5.00 \mathrm{pm}$. The patients received their prednisone as a single dose at 7.00 am of the 'day on', which allowed at least one hour for the absorption of the drug before the studies were begun.

Functional residual capacity (FRC), total lun capacity (TLC), and airway resistance (Raw) were determined by the technique of DuBois et a $\vec{\Phi}$ (1956a) and DuBois, Botelho, and Comroe 
T A B L E I

ALTERNATE-DAY PREDNISONE THERAPY OF PATIENTS WITH MYASTHENIA GRAVIS

\begin{tabular}{|c|c|c|c|c|c|c|c|c|}
\hline Patient & Age & Sex & Wt(kg) & $\mathrm{Ht}(\mathrm{cm})$ & $\begin{array}{l}\text { Date of First } \\
\text { Symptoms }\end{array}$ & $\begin{array}{l}\text { Date Prednisone } \\
\text { Started }\end{array}$ & $\begin{array}{l}\text { Present Therapy } \\
\text { Prednisone (mg) }\end{array}$ & Date Studied \\
\hline $\begin{array}{l}1 \\
2 \\
3 \\
4 \\
5 \\
5 \\
6 \\
7 \\
8\end{array}$ & $\begin{array}{l}34 \\
57 \\
70 \\
39 \\
52 \\
58 \\
16 \\
49\end{array}$ & $\begin{array}{l}\mathbf{M} \\
\mathbf{M} \\
\mathbf{M} \\
\mathbf{F} \\
\mathbf{F} \\
\mathbf{F} \\
\mathbf{F} \\
\mathbf{M}\end{array}$ & $\begin{array}{l}92 \\
81 \\
81 \\
60 \\
95 \\
54 \\
55 \\
99\end{array}$ & $\begin{array}{l}175 \\
178 \\
169 \\
160 \\
163 \\
160 \\
165 \\
176\end{array}$ & $\begin{array}{l}\text { July } 1970 \\
\text { April } 1972 \\
\text { January } 1972 \\
\text { July } 1961 \\
\text { February } 1967 \\
\text { May } 1963 \\
\text { October } 1972 \\
\text { October } 1971\end{array}$ & $\begin{array}{l}\text { September } 1972 \\
\text { September } 1972 \\
\text { September } 1972 \\
\text { June } 1971 \\
\text { October } 1971 \\
\text { September } 1970 \\
\text { September } 1973 \\
\text { January } 1972\end{array}$ & $\begin{array}{r}100 \\
110 \\
70 \\
45 \\
100 \\
70 \\
50 \\
100\end{array}$ & $\begin{array}{l}\text { September } 1973 \\
\text { October } 1973 \\
\text { October } 1973 \\
\text { October } 1973 \\
\text { October } 1973 \\
\text { November } 1973 \\
\text { November } 1973 \\
\text { March } 1973\end{array}$ \\
\hline
\end{tabular}

T A B L E I I

EFFECTS ON RESPIRATORY FUNCTION OF ALTERNATE-DAY PREDNISONE IN MYASTHENIA GRAVIS

\begin{tabular}{|c|c|c|c|c|c|c|}
\hline Patient & FVC(1.) & $\mathrm{FEV}_{1}(1)$. & $\mathbf{M M F}(\mathbf{l} / \mathbf{s})$ & $\operatorname{PF}(1 / \mathrm{min})$ & MVV(1/min) & Di.co(ml min-1 torr $\left.{ }^{-1}\right)$ \\
\hline $\begin{array}{l}1 \\
2 \\
3 \\
4 \\
5 \\
6 \\
7 \\
8\end{array}$ & $\begin{array}{l}3 \cdot 12(3 \cdot 37) \\
4 \cdot 61(4 \cdot 74) \\
2 \cdot 92(2 \cdot 89) \\
3 \cdot 27(3 \cdot 29) \\
2 \cdot 90(3 \cdot 02) \\
2 \cdot 71(2 \cdot 69) \\
3 \cdot 04(2 \cdot 82) \\
3 \cdot 02(3 \cdot 50)\end{array}$ & $\begin{array}{l}2 \cdot 25(2 \cdot 50) \\
3 \cdot 49(3 \cdot 61) \\
2 \cdot 25(2 \cdot 20) \\
2 \cdot 81(2 \cdot 81) \\
2 \cdot 35(2 \cdot 40) \\
2 \cdot 02(2 \cdot 00) \\
2 \cdot 91(2 \cdot 79) \\
1 \cdot 67(1 \cdot 91)\end{array}$ & $\begin{array}{l}1 \cdot 65(2 \cdot 05) \\
3 \cdot 38(3 \cdot 44) \\
2 \cdot 22(2 \cdot 34) \\
3 \cdot 95(3 \cdot 80) \\
2 \cdot 70(2 \cdot 56) \\
2 \cdot 00(2 \cdot 16) \\
4 \cdot 00(4 \cdot 66) \\
0 \cdot 85(0 \cdot 86)\end{array}$ & $\begin{array}{l}363(422) \\
672(666) \\
322(318) \\
382(412) \\
307(310) \\
221(210) \\
355(348) \\
165(195)\end{array}$ & $\begin{array}{c}93(116) \\
171(172) \\
94(106) \\
106(111) \\
85(90) \\
89(90) \\
100(87) \\
49(47)\end{array}$ & $\begin{array}{l}22 \cdot 8(25 \cdot 3) \\
22 \cdot 0(21 \cdot 9) \\
21 \cdot 0(21 \cdot 5) \\
22 \cdot 4(21 \cdot 6) \\
18 \cdot 6(19 \cdot 5) \\
23 \cdot 7(24 \cdot 1) \\
27 \cdot 3(26 \cdot 9) \\
28 \cdot 8(24 \cdot 9)\end{array}$ \\
\hline $\begin{array}{l}\text { Mean } \\
\% \text { change' } \\
\text { SE } \\
\text { P }\end{array}$ & $\begin{array}{l}0.43 \\
1.64 \\
\text { NS }\end{array}$ & $\begin{array}{l}0.83 \\
1.75 \\
\text { NS }\end{array}$ & $\begin{array}{l}9 \cdot 95 \\
4 \cdot 84 \\
\text { NS }\end{array}$ & $\begin{array}{l}3 \cdot 55 \\
2 \cdot 71 \\
\text { NS }\end{array}$ & $\begin{array}{l}5 \cdot 90 \\
3 \cdot 92 \\
\text { NS }\end{array}$ & $\begin{array}{l}3.29 \\
1.94 \\
\text { NS }\end{array}$ \\
\hline
\end{tabular}

Numbers outside parentheses are from 'day off' and numbers within parentheses from 'day on' prednisone. Numbers represent the mean of all observations for the day.

'Numbers represent average percentage change of 'day off' to 'day on' for eight patients.

(1956b). The FRC was also determined by helium dilution (Meneely and Kaltreider, 1949). Spirometric tests-forced vital capacity (FVC), expiratory volume in the first second $\left(F E V_{1}\right)$, maximal mid-expiratory flow (MMF) and peak flow (PF), and the maximal voluntary ventilation (MVV)were determined with a Stead-Wells spirometer (Warren E. Collins); the diffusing capacity (DLco) was determined by the single-breath technique (Gaensler and Smith, 1973). The diffusing capacity, FRC, TLC, and Raw at each time interval represent the mean of three measurements. Spirometric tests at each time interval represent the best of three measurements. Arterial blood gases were measured in duplicate with standard electrodes (Radiometer Model BMS3). The data were analysed by the Student's $t$ test for paired observations.

\section{RESULTS}

Routine pulmonary function results in the eight patients were within predicted norms (Kory et al., 1961; Boren, Kory, and Syner, 1966) except those of subject 8 , which showed airways obstruction. Tables II and III show the effects of alternate-day prednisone therapy on respiratory function in the eight patients. These data of two consecutive days - a 'day on' and a 'day off' prednisone-represent the average of the respective four determinations for the 'day off' versus the 'day on'. Several studies were obtained throughout the day because preliminary data on subject 8 showed large intra-

\section{T A B L E I I I}

EFFECTS ON RESPIRATORY FUNCTION OF ALTERNATEDAY PREDNISONE IN MYASTHENIA GRAVIS

\begin{tabular}{|c|c|c|c|}
\hline Patient & TLC(I) & FRC(l) & $\mathrm{Raw}\left(\mathrm{cmH}_{2} \mathrm{O} \mathrm{I}^{-1} \mathrm{~s}\right)$ \\
\hline $\begin{array}{l}1 \\
2 \\
3 \\
4 \\
5 \\
6 \\
7 \\
8\end{array}$ & $\begin{array}{c}5 \cdot 54(5 \cdot 86) \\
7 \cdot 42(7 \cdot 78) \\
4 \cdot 87(5 \cdot 18) \\
5 \cdot 05(4 \cdot 97) \\
5 \cdot 06(5 \cdot 27) \\
5 \cdot 61(5 \cdot 30) \\
5 \cdot 67(5 \cdot 72) \\
11 \cdot 67(10 \cdot 16)\end{array}$ & $\begin{array}{l}2 \cdot 92(3 \cdot 06) \\
3 \cdot 87(4 \cdot 28) \\
2 \cdot 60(2 \cdot 64) \\
2 \cdot 55(2 \cdot 48) \\
2 \cdot 66(2 \cdot 71) \\
3 \cdot 71(3 \cdot 40) \\
3 \cdot 72(3 \cdot 71) \\
9 \cdot 16(7 \cdot 54)\end{array}$ & $\begin{array}{l}2 \cdot 01(1 \cdot 37) \\
0 \cdot 70(0.74) \\
1 \cdot 20(0.82) \\
1 \cdot 02(1 \cdot 01) \\
0.79(0.73) \\
2 \cdot 02(2 \cdot 02) \\
1 \cdot 30(1.33) \\
4 \cdot 26(3.65)\end{array}$ \\
\hline $\begin{array}{c}\text { Mean } \\
\% \text { change' } \\
\text { SE } \\
P\end{array}$ & $\begin{array}{l}0.04 \\
2 \cdot 32 \\
\text { NS }\end{array}$ & $\begin{array}{c}-1 \cdot 35 \\
3 \cdot 04 \\
\text { NS }\end{array}$ & $\begin{array}{c}-9 \cdot 85 \\
5 \cdot 27 \\
\text { NS }\end{array}$ \\
\hline
\end{tabular}

Numbers outside parentheses are from 'day off' and numbers within parentheses from 'day on' prednisone. Numbers represent the mean of all observations for the day.

'Numbers represent average percentage change of 'day off' to 'day on' for eight patients. 
day variation in lung function, which later proved to be a result of obstructive lung disease rather than a result of alternate-day prednisone therapy (Fig. 1). Except in subject 8, there were no significant intra-day changes. Patient 1 showed improvement of all parameters from the 'day off' to the 'day on' (Tables II and III). Patient 8 had a decrease of TLC, FRC, and RV from the 'day off' to the 'day on' (Fig. 1) with an increase in FVC and $\mathrm{FEV}_{1}$. Because of his obstructive lung disease with hyperinflation, this represented improved respiratory function. In patient 8 , this pattern of better respiratory function during the 'day on' has now persisted for about two years. As a group, there were no significant changes of any of the parameters from the 'day off' to the 'day on' prednisone. These patients have been followed for periods of months to over two years, and repeated pulmonary function studies over that time have shown no consistent differences between

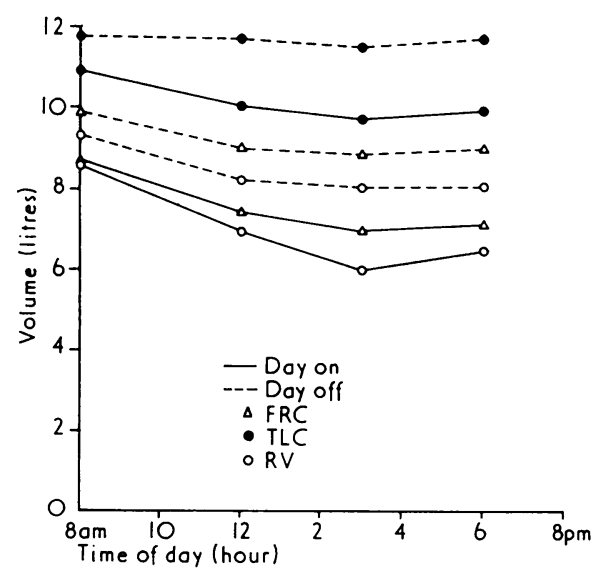

FIG. 1. Patient 8. Lung volumes determined plethysmographically. Volumes show intra- and inter-day fluctuation.

T A B L E I V

ARTERIAL BLOOD GASES OF PATIENTS WITH MYASTHENIA GRAVIS ON ALTERNATE-DAY PREDNISONE

\begin{tabular}{|c|c|c|c|}
\hline Patient & $\mathrm{pH}$ & $\mathrm{PCO}_{2}$ & $\mathrm{Po}_{2}$ \\
\hline $\begin{array}{l}1 \\
2 \\
3 \\
4 \\
5 \\
6 \\
7\end{array}$ & $\begin{array}{l}7.42 \\
7.37 \\
7.40 \\
7.41 \\
7.46 \\
7 \cdot 46\end{array}$ & $\begin{array}{l}38 \cdot 0 \\
38.1 \\
40 \cdot 8 \\
31.8 \\
34 \cdot 2 \\
32 \cdot 0\end{array}$ & $\begin{array}{r}77 \cdot 0 \\
77.1 \\
85.3 \\
95.6 \\
81.0 \\
101.2\end{array}$ \\
\hline 8 & $\overline{7 \cdot 42}$ & $\overline{45 \cdot 0}$ & $\overline{71 \cdot 0}$ \\
\hline
\end{tabular}

'day on' and 'day off' with the exception of sub- $\overrightarrow{\vec{\omega}}$ jects 1 and 8. Table IV shows that, except for ato decreased $\mathrm{Pco}_{2}$ in patients 4 and 6 (indicating $\frac{0}{0}$ hyperventilation), and a decreased $\mathrm{Po}_{2}$ in patient $\frac{}{2}$ 8 (probably secondary to obstructive lung disease), $\overparen{\otimes}$ the arterial blood gases measured during the 'day off' prednisone (when one might expect to see ${ }^{\infty}$ abnormalities, if there were any) are within $\vec{\circ}$ normal limits.

\section{DISCUSSION}

Tables II and III show that even though there are large individual changes of respiratory function, for the patients as a group there were no signifi- $\vec{A}$ cant differences between 'day off' and 'day on'. Our studies indicate that patients without underlying lung disease do not have large changes in $\vec{D}$ pulmonary function from the 'day on' to the 'day off' prednisone. Even though the reported data $\frac{\text { D }}{5}$ are only from two consecutive days, repeated pulmonary function tests obtained over periods of $\vec{\varphi}$ months to over two years, during follow-up visits. of the patients, show that with the exception of subject 8 (who shows progressive obstructive lung disease as a result of smoking two packs of $\frac{\partial}{\partial}$ cigarettes per day), there have been only minor

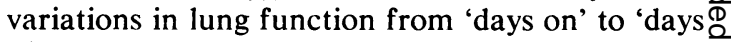
off'.

In our experience, when patients start prednisone therapy they show obvious differences in respiratory strength from the 'day on' to the 'dayo off'. During these early stages of therapy patients can remain off the mechanical ventilator foro longer periods of time and have greater vital $\underset{x}{\stackrel{0}{0}}$ capacities during the 'day on'. Electromyographico evaluation of neuromuscular synaptic efficiency $\underset{3}{3}$. confirms that during the early stages of prednisone? therapy muscle strength is greater during the 'dayß on' (Warmolts and Engel, 1972). The mechanismo by which prednisone increases muscle strength in these patients is not well understood (Engel and을 Warmolts, 1971). Later on these differences of $\mathrm{N}$ 'day on' versus 'day off' become smaller and mayo disappear in some patients.

Subject 1 has consistently shown a minor im-N provement in all pulmonary function parameterso during his day on prednisone (Tables II and III) However, because he has no major underlying lung disease, these changes are probably physio-logically unimportant for him. In contrast to subject 8 , he has no major diurnal variation ofo lung function (Fig. 2). Subject 8 shows major $\vec{\Phi}$ diurnal, as well as 'day on' to 'day off' changes inष्ठ lung function (Tables II and III; Fig. 1). 


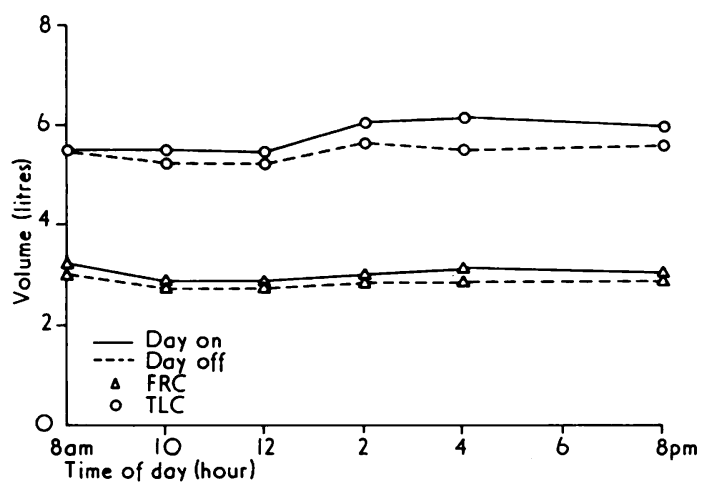

FIG. 2. Patient 1. Lung volumes measured plethysmographically. Volumes show little intra- or inter-day fluctuation.

Patients with myasthenia gravis develop a 'crisis' whenever severe respiratory distress and ventilatory inadequacy occur. A crisis may result from undertreatment or overtreatment with anticholinesterases, or decreased responsiveness to those drugs. All our patients except patient 8 were placed on prednisone therapy because of decreased responsiveness to anticholinesterase drugs leading to myasthenic crises. During the year preceding prednisone therapy, while being treated with anticholinesterase drugs, patients 1 to 7 had one or more episodes of acute respiratory insufficiency associated with generalized weakness, all requiring tracheostomy. Since being treated with prednisone alone, for periods up to three years (Table I), none of the patients has had a myasthenic crisis or any episodes of acute respiratory insufficiency, and respiratory function has in general remained stable during the day. This contrasts with patients on anticholinesterase therapy in whom the FVC may fall substantially several times a day just before the administration of anticholinesterase drugs (Osserman and Genkins, 1971). Thus alternate-day prednisone therapy not only decreases the frequency of myasthenic crises but also provides a smoother course of therapy when compared to previous treatment with anticholinesterase drugs.
We are indebted to Drs. Harold Menke; and Claude Lenfant for their suggestions.

\section{REFERENCES}

Boren, H. G., Kory, R. C., and Syner, J. C. (1966). The Veterans Administration-Army $\mathrm{Co}$ operative study of pulmonary function. 2. The lung volume and its subdivisions in normal men. American Journal of Medicine, 41, 96.

DuBois, A. B., Botelho, S. Y., Bedell, G. N., Marshall, R., and Comroe, J. H., Jr. (1956a). A rapid plethysmographic method for measuring thoracic gas volume: a comparison with a nitrogen washout method for measuring functional residual capacity in normal subjects. Journal of Clinical Investigation, 35, 322.

- - _ , and Comroe, J. H., Jr. (1956b). A new method for measuring airway resistance in man using a body plethysmograph: values in normal subjects and in patients with respiratory disease. Journal of Clinical Investigation, 35, 327.

Engel, W. K. and Warmolts, J. R. (1971). Myasthenia gravis: a new hypothesis of the pathogenesis and a new form of treatment. Annals of the New York Academy of Sciences, 183, 72.

Gaensler, E. A. and Smith, A. A. (1973). Attachment for automated single breath diffusing capacity measurement. Chest, 63, 136.

Harter, J. G., Reddy, W. J., and Thorn, G. W. (1963). Studies on an intermittent corticosteroid dosage regimen. New England Journal of Medicine, 269, 591.

Kory, R. C., Callahan, R., Boren, H. G., and Syner, J. C. (1961). Clinical spirometry in normal men. A merican Journal of Medicine, 30, 243.

Meneely, G. R. and Kaltreider, N. L. (1949). The volume of the lung determined by helium dilution: description of the method and comparison with other procedures. Journal of Clinical Investigation, 28, 129.

Osserman, K. E. and Genkins, G. (1971). Studies in myasthenia gravis: review of a twenty-year experience in over 1200 patients. Mount Sinai Journal of Medicine, 38, 497.

Warmolts, J. R. and Engel, W. K. (1972). Benefit from alternate-day prednisone in myasthenia gravis. New England Journal of Medicine, 286, 17.

Requests for reprints to: Harold H. Newball, Respiratory Division, The Johns Hopkins University School of Medicine, 5601 Loch Raven Boulevard, Baltimore, Md 21239, USA. 